University of Nebraska - Lincoln

DigitalCommons@University of Nebraska - Lincoln

Faculty Publications from the Harold W. Manter Laboratory of Parasitology

4-2005

\title{
Species of Gorgoderina (Digenea: Gorgoderidae) in Rana vaillanti and Rana Cf. forreri (Anura: Ranidae) from Guanacaste, Costa Rica, including a Description of a New Species
}

\author{
Rosario Mata-López \\ Universidad Nacional Autónoma de México \\ Virginia León-Règagnon \\ Universidad Nacional Autónoma de México \\ Daniel R. Brooks \\ University of Toronto,dnlbrooks@gmail.com
}

Follow this and additional works at: https://digitalcommons.unl.edu/parasitologyfacpubs

Part of the Parasitology Commons

Mata-López, Rosario; León-Règagnon, Virginia; and Brooks, Daniel R., "Species of Gorgoderina (Digenea: Gorgoderidae) in Rana vaillanti and Rana Cf. forreri (Anura: Ranidae) from Guanacaste, Costa Rica, including a Description of a New Species" (2005). Faculty Publications from the Harold W. Manter Laboratory of Parasitology. 277.

https://digitalcommons.unl.edu/parasitologyfacpubs/277

This Article is brought to you for free and open access by the Parasitology, Harold W. Manter Laboratory of at DigitalCommons@University of Nebraska - Lincoln. It has been accepted for inclusion in Faculty Publications from the Harold W. Manter Laboratory of Parasitology by an authorized administrator of DigitalCommons@University of Nebraska - Lincoln. 


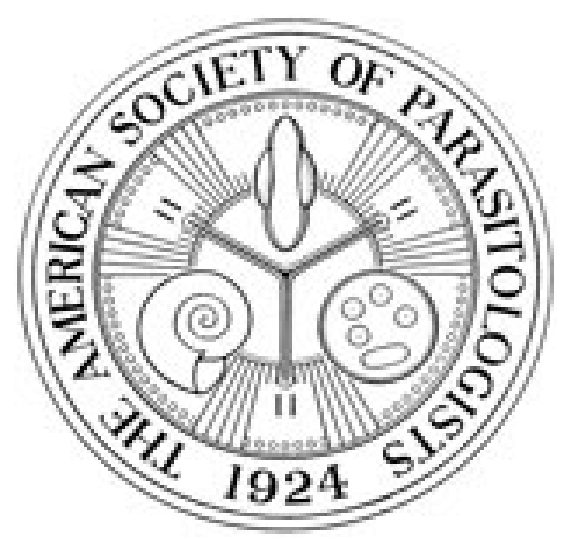

Species of Gorgoderina (Digenea: Gorgoderidae) in Rana vaillanti and Rana Cf. Forreri (Anura: Ranidae) from Guanacaste, Costa Rica, including a Description of a New Species Author(s): Rosario Mata-López, Virginia León-Règagnon, Daniel R. Brooks

Source: The Journal of Parasitology, Vol. 91, No. 2 (Apr., 2005), pp. 403-410

Published by: The American Society of Parasitologists

Stable URL: http://www.jstor.org/stable/3286438

Accessed: $30 / 04 / 201012: 56$

Your use of the JSTOR archive indicates your acceptance of JSTOR's Terms and Conditions of Use, available at http://www.jstor.org/page/info/about/policies/terms.jsp. JSTOR's Terms and Conditions of Use provides, in part, that unless you have obtained prior permission, you may not download an entire issue of a journal or multiple copies of articles, and you may use content in the JSTOR archive only for your personal, non-commercial use.

Please contact the publisher regarding any further use of this work. Publisher contact information may be obtained at http://www.jstor.org/action/showPublisher?publisherCode=asp.

Each copy of any part of a JSTOR transmission must contain the same copyright notice that appears on the screen or printed page of such transmission.

JSTOR is a not-for-profit service that helps scholars, researchers, and students discover, use, and build upon a wide range of content in a trusted digital archive. We use information technology and tools to increase productivity and facilitate new forms of scholarship. For more information about JSTOR, please contact support@ jstor.org.

The American Society of Parasitologists is collaborating with JSTOR to digitize, preserve and extend access to The Journal of Parasitology. 


\title{
SPECIES OF GORGODERINA (DIGENEA: GORGODERIDAE) IN RANA VAILLANTI AND RANA CF. FORRERI (ANURA: RANIDAE) FROM GUANACASTE, COSTA RICA, INCLUDING A DESCRIPTION OF A NEW SPECIES
}

\author{
Rosario Mata-López, Virginia León-Règagnon*, and Daniel R. Brooks $\dagger$ \\ Departamento de Zoología, Instituto de Biología, UNAM, Apdo Postal 70-153, C.P. 04510, México, D. F. México. e-mail: \\ vleon@ibiologia.unam.mx
}

\begin{abstract}
Gorgoderina parvicava, G. diaster, and G. megacetabularis $\mathrm{n}$. sp. are reported inhabiting the urinary bladders of Rana vaillanti and $R$. cf. forreri from northwestern Costa Rica. Gorgoderina megacetabularis $\mathrm{n}$. sp. differs from all other species of the genus by the combination of the following characters: small body size (2.78-3.17, mean $2.92 \mathrm{~mm})$, sucker ratio (1:3.13.7 ), and by the presence of 2 compact, oval, unlobed vitelline masses. Redescription of $G$. diaster including previously undescribed details on the reproductive apparatus and morphometric data is provided. This is the first record of the 3 species of Gorgoderina in Costa Rica and is the first record of $G$. diaster in $R$. vaillanti and $R$. cf. forreri.
\end{abstract}

The digenean Gorgoderina comprises 51 described species, all of which are parasites in the urinary bladder of anurans and caudates (Amphibia) throughout the world. Approximately half of them are distributed in North and South America. As part of an inventory of eukaryotic parasites of vertebrates in the Área de Conservación de Guanacaste (ACG) in Costa Rica, specimens of 3 species of Gorgoderina were collected including an undescribed species, inhabiting Rana vaillanti or $R$. cf. forreri (or both).

Rana vaillanti Brocchi, 1877 is distributed in low and moderate elevations from southern México (Veracruz, Oaxaca, and Chiapas states) (Meyer and Wilson, 1971) through the Pacific slope down to Colombia and Ecuador (Hillis and de Sá, 1988). Few helminthological studies of this amphibian species have been conducted, most of them in México (Razo-Mendivil et al., 1999; Guillén-Hernández et al., 2000; Pérez-Ponce de León et al., 2000; Goldberg et al., 2002; Paredes-Calderón et al., 2004) and 2 records in Costa Rica (Zelmer and Brooks, 2000; LeónRègagnon et al., 2001; Rodríguez-Ortíz et al., 2003). These studies have reported 25 helminth species parasitizing $R$. vaillanti.

Rana forreri Boulenger, 1883 was previously considered to occur along the Pacific coastal plain and adjacent lowlands of México and Central America (Flores-Villela et al., 1995), although molecular evidence indicates (Hillis et al., 1983; Zaldivar-Riverón et al., 2004) it is a composite taxon. Specimens in Costa Rica previously considered to be $R$. forreri presumably constitute an undescribed species of this group of frogs. Only 4 parasitological studies of this amphibian species complex have been conducted; 3 in México (Pérez-Ponce de León et al., 2000; Goldberg and Bursey, 2002; Cabrera-Guzmán et al., 2004) and 1 in Costa Rica (Desser, 2001; Rodríguez-Ortíz et al., 2003). These studies have reported 23 parasite taxa. Most of them dealt with nematodes having direct life cycles that reflect the more terrestrial character of this amphibian species complex().

\section{MATERIALS AND METHODS}

Between 1998 and 1999, specimens of $R$. vaillanti and $R$. cf. forreri were collected in various parts of the ACG, Costa Rica. Hosts were

Received 13 January 2004; revised 7 April 2004; 24 June 2004; accepted 9 July 2004.

* To whom correspondence should be addressed.

$\dagger$ Department of Zoology, University of Toronto, Canada, 25 Harbord Street, Toronto, Ontario, Canada M5S 3G5. examined for helminth parasites. Specimens of Gorgoderina spp. were removed from the urinary bladder and placed in saline solution $(0.6 \%)$, fixed in hot $4 \%$ formaldehyde, and preserved in $70 \%$ ethanol. Some specimens were stained in Mayer's paracarmine or Gomori's trichrome, dehydrated, cleared in methyl salicylate, and whole mounted in Canada balsam. Figures were drawn with the aid of a drawing tube. Measurements are presented as range with mean in parentheses and expressed in micrometers $(\mu \mathrm{m})$. Specimens for scanning electron microscopy were dehydrated with a graded series of ethanol and critical-point dried with $\mathrm{CO}_{2}$, then covered with gold-palladium mixture. They were examined using a Hitachi S2460N electron microscope. The following abbreviations are used: CHCR, Colección Helmintológica de Costa Rica; CNHE, Colección Nacional de Helmintos, Instituto de Biología, Universidad Nacional Autónoma de México; CHIOC, Coleção Helmintológica do Instituto Oswaldo Cruz Fundação Instituto Oswaldo Cruz, Río de Janeiro, Brazil; HWML, Harold W. Manter Laboratory of Parasitology, Lincoln, Nebraska; NHM, Natural History Museum, London, U.K.; NBM, New Brunswick Museum, New Brunswick, Canada; USNPC, United States National Parasite Collection, Beltsville, Maryland(). The following specimens were examined for comparison: G. alobata NHM, 1965.6.25. 1-2; G. attenuata CNHE, 1178-1180, 1182, 1446, 1544$1548,2416,3401-3405,3412,3413,3793$; HWML, 740, 17079, 20121-20126, 20888, 20955, 21344, 21949, 24898, 31259, 33206; USNPC, 051644.00, 075452.00, 081464.00; NBM, 3542 and 10 not cataloged slides; $G$. diaster CHIOC, 17426, 25255, 25256; HWML, 20250; NHM, 1980.11.12.7-8 and 1 slide from the reference collection of D. R. Brooks; G. intermedia USNPC, 007996.00; G. parvicava CNHE, 1177, 2415; CHIOC, 19076, 21076, 21509-21511, 21871$21877,25261,25262,25264,25269,25271-25279,25284,25288$, 25290, 29043, 34171; NHM, 1988.9.15.9; G. tепиа USNPC, 008976.00; G. vitelliloba NHM, 1933.7.19.22, 1937.6.8.151, 1946.5.8.182, 1975. 8.16.113-114, 1976.4.9.18-22, 1983.6.9.3, 1984.10.9.16; HWML, 34301. Prevalence and intensity are used following Margolis et al. (1982).

\section{DESCRIPTION \\ Gorgoderina megacetabularis n. sp. (Figs. 1-4)}

Description (based on 46 specimens): Measurements based on 13 mature specimens. Body spindle shaped, blunt anterior end, pointed posterior end; body length (BL) 2,780-3,170 $(2,920)(\mathrm{n}=7)$. Forebody $340-680(520)$ long $(12.2-21.4 \%$ [17.8\%] of BL) $(n=7), 160-220(190)(n=7)$ wide at level of cecal bifurcation. Hindbody 1,110-1,770 (1,580) long (39.9$55.8 \%$ [51.1\%] of BL) $(n=7), 240-290(270)(n=7)$ wide at level of anterior testis (Fig. 1). Tegumental surface aspinose, with numerous regular ridges surrounding body, covered with knoblike protuberances. Numerous large papillae present on tegument, concentrating on oral sucker and on the region between both suckers (Figs. 2, 3A, B). 


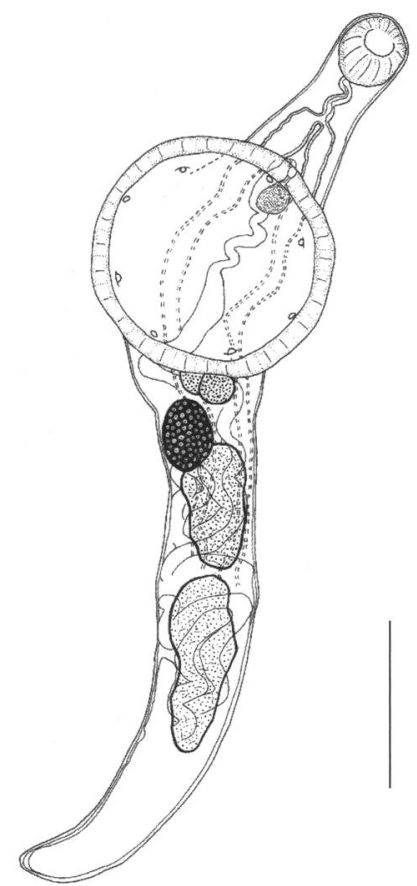

FIGURE 1. Gorgoderina megacetabularis n. sp. ventral view. Bar $=$ $50 \mu \mathrm{m}$.

Oral sucker subterminal, spherical (Fig. 2), 180-250 (210) long, 170-220 (200) wide ( $\mathrm{n}=9$ ); 5 pairs of papillae surrounding oral opening (Fig. 2a-e). Four additional pairs of papillae flanking the stylet pit on apical region of body (Fig. 3C); 1 pair of papillae on dorsal border of oral opening (Figs. 2f; 3A), and 1 pair on lateral borders of oral aperture (Fig. 2g); 2 extra pairs are located on the oral cavity (Fig. 2h, i). Small papillae on the oral sucker surface, arrangement varying among examined specimens (Fig. 3A). Pharynx absent. Esophagus curved, thick walled, 140-230 (190) long (5-7.25\% [6.5\%] of BL) $(n=10)$. Intestinal bifurcation 250-360 (330) (8.99-11.35\% [11.3\%] of $\mathrm{BL})(\mathrm{n}=10)$ from anterior end of body. Ceca simple, initial portion wider and lobed; ceca ending at 170-400 (260) (6.1$12.6 \%[8.9 \%]$ of BL) $(\mathrm{n}=8)$ from posterior extremity (Fig. 1).

Ventral sucker in anterior third of body; 380-740 (560) long, $510-730(600)$ wide $(n=6)$. Eight papillae on internal surface of acetabulum (Fig. 1); 2 pairs lateral to longitudinal axis, covered with flattened scales (Fig. 3D); 1 pair of simple papillae located on middle line of longitudinal axis of sucker and 1 additional pair on transversal axis (Fig. 3E). Sucker ratio 1:3.13.7 (3.43).

Testes 2, elongate, borders irregular, sometimes bilobed, in tandem, intercecal, postequatorial, at 84-570 (215) (3-18\% [7.36\%] of $\mathrm{BL})(\mathrm{n}=10)$ from posterior margin of ventral sucker. Anterior testis smaller than posterior testis, sometimes partially overlapping one another. Anterior end of anterior testis overlapping posterior end of ovary; 200-430 (340) long, 90250 (170) wide, 150-220 (180) deep $(\mathrm{n}=12)$. Posterior testis 330-730 (530) long, 140-270 (180) wide, 130-220 (170) deep $(\mathrm{n}=11)$. Vas deferens runs anteriorly. Seminal vesicle oval or spherical, dorsal to the anterior edge of acetabulum; 57-210 (130) long, 70-140 (110) wide, 90-210 (140) deep $(\mathrm{n}=10)$. Distal end of seminal vesicle surrounded by prostatic cells;

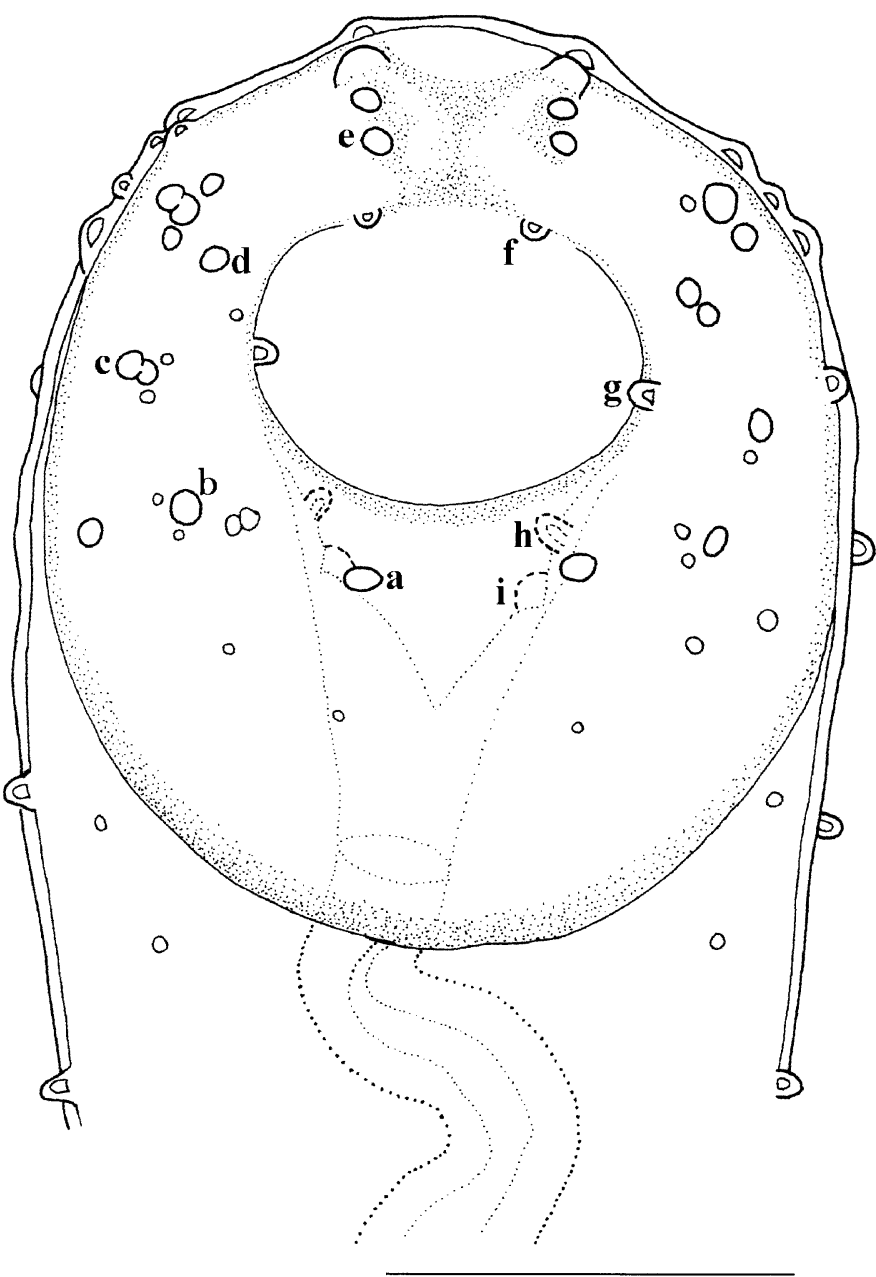

FIGURE 2. Gorgoderina megacetabularis $\mathrm{n}$. sp. Oral sucker. (a-e) 5 pairs of papillae surrounding oral opening; $(\mathbf{f}-\mathbf{i}) 4$ pairs of papillae in the oral opening. Bar $=20 \mu \mathrm{m}$.

opening into genital atrium. Genital pore anterior to ventral sucker, medially, at 400-520 (570) (14.4-16.4\% [19.5\%] of BL) $(n=5)$ from anterior extremity of body (Fig. 1). Ovary oval, dextral (in 39 of the 46 specimens), posterior to vitellaria, at 50-160 (100) (1.8-5.0\% [3.42\%] of BL) $(\mathrm{n}=3)$ from posterior end of acetabulum, 180-250 (220) long, 130-170 (140) wide, 130-160 (140) deep $(n=11)$. Vitellaria 2, compact oval masses, immediately posterior to acetabulum on middle line of body (Fig. 4A). Dextral vitelline gland 81-130 (110) long, 79120 (90) wide, 80-130 (110) deep $(\mathrm{n}=12)$; left vitelline gland 80-140 (110) long, 70-130 (100) wide, 60-120 (90) deep (n =12). Mehlis' gland and Laurer's canal not observed. Uterine loops filling postacetabular region and overlapping dorsally and ventrally with testes, partially overlapping ovary and vitelline glands, opening to genital atrium (Fig. 4B). Eggs thin shelled, embryonated, 25-32 (28) long, 15-20 (17) wide. Excretory vesicle could not be observed. Excretory pore terminal (Fig. 3F).

\section{Taxonomic summary}

Type host: Rana vaillanti Brocchi, 1877 (Anura: Ranidae). Site of infection: Urinary bladder.

Prevalence, intensity: See Table II. 

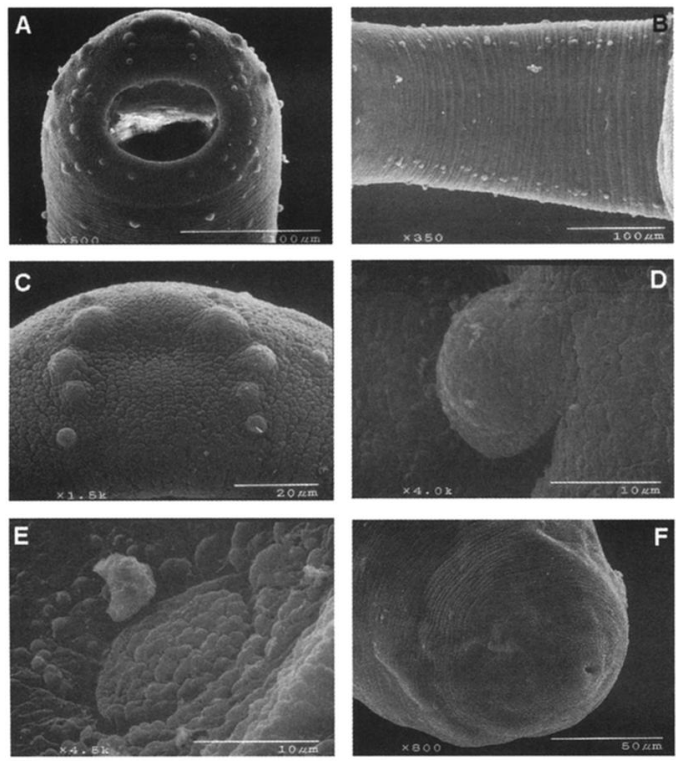

FIGURE 3. SEM photomicrographs of Gorgoderina megacetabularis n. sp. A. Oral sucker. B. Preacetabular region. C. Stylet pit. D. Acetabular papilla covered with flattened scales. E. Acetabular simple papilla. F. Body posterior extremity.

Co-occurrence: Gorgoderina megacetabularis n. sp. co-occurred with $G$. parvicava in 2 hosts and with $G$. diaster in 2 hosts.

Type locality: Río Pizote between Brasilia and Dos Ríos, sector San Gerardo (San Cristóbal), ACG, Costa Rica.

Other localities: Río Pizote, sector Santa Rosa and Sector Caribe, ACG, Costa Rica.

Type specimens: Holotype, CNHE 5000; paratypes, CNHE 5001, USNPC 94751, 94752, CHCR 115; vouchers, CNHE 5002, USNPC 94793, 94754.

Etymology: The specific epithet refers to the size of the ventral sucker, which is relatively much larger than that for any other known species in the genus.

\section{Remarks}

The new species differs from all the described species of Gorgoderina in having a sucker ratio of 1:3.1-3.7; G. insularis Richard, Chabaud and Brygoo, 1968, which occurs in Ptychadena mascareniensis in Madagascar has a sucker ratio averaging 1:2.4 and is most similar in this regard (Table I).

Fully ovigerous specimens of $G$. megacetabularis n. sp. are small, thus resembling G. alobata Lees and Mitchell, 1966, G. attenuata (Stafford, 1902) Stafford, 1905, G. carli Baer, 1930, G. chilensis Dioni, 1947, G. darwini Mañé-Garzón and González, 1978, G. intermedia Holl, 1928, G. insularis, G. gracilis Wongsawad et al., 1999, G. tenua Rankin, 1937, G. symmetriorchis Dwivedi, 1968, and G. vitelliloba Olsson, 1876. In addition to the sucker ratio, the new species differs from $G$. attenuata, G. chilensis, G. darwini, G. intermedia, G. insularis, G. tenua, and $G$. vitelliloba by having vitelline glands arranged in 2 compact, unlobed oval masses, whereas the vitellaria are lobed in all other small species of Gorgoderina.

The new species most closely resembles $G$. alobata, which occurs in Bombina variegata in Europe, by having small body

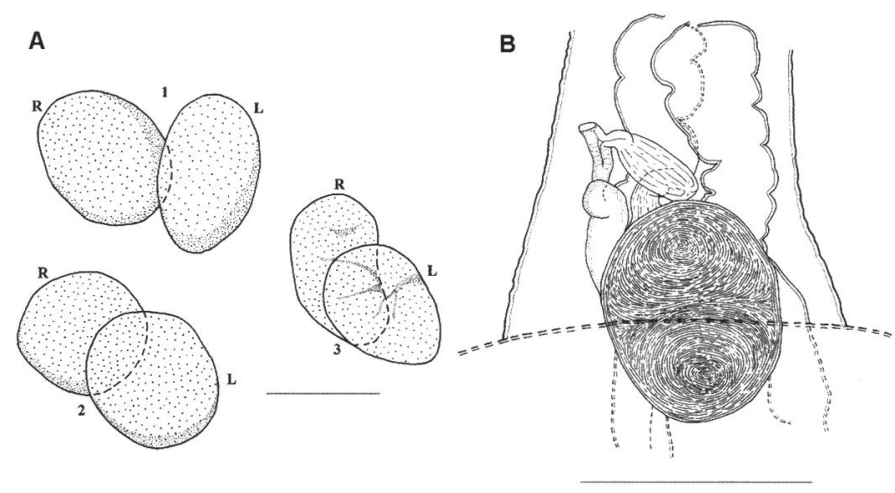

FIGURE 4. Gorgoderina megacetabularis n. sp. A. Vitellaria from 3 specimens; 1 and 2 ventral view, 3 lateral view ( $\mathrm{L}$ left vitellaria, $\mathrm{R}$ right vitellaria). B. Ventral view of seminal vesicle and genital atrium. Bar $=100 \mu \mathrm{m}$.

size and unlobed vitellaria. However, G. alobata has a sucker ratio of $1: 1$ and intestinal ceca extending only to the level of the posterior end of the posterior testis, whereas in the new species they reach two thirds the way between the posterior testis and the posterior end of the body.

\section{REDESCRIPTION}

\section{Gorgoderina diaster Lutz, 1926 (Fig. 5)}

Six specimens were collected in 2 hosts. Measurements are based on 3 mature specimens. Body length 7,820-7,910 $(7,860)$, maximum wide at level of posterior testis $930(11.8 \%$ of BL). Forebody 810-1,020 (915) long (10.35-12.89\% [11.64\%] of BL), 750 wide at level of cecal bifurcation; hindbody 6,311 long ( $80.3 \%$ of BL), 930 maximum wide. Oral sucker subterminal, spherical, 480 in diameter. Pharynx absent. Esophagus long and curved. Intestinal bifurcation 740 (9.35$9.5 \%$ of BL) from anterior end of body. Ceca simple and lobed; right cecum ending at 350-850 (620) (4.5-10.7\% [7.9\%] of BL) from posterior extremity; left cecum at 350-550 (460) (4.5-6.95\% [5.85\%] of BL) (Fig. 5A). Four penetration glands on each side of the oral sucker, opening dorsally, anterior to this structure. Ventral sucker at 3,200 (41\% of BL) from anterior end, 700-780 (730) long, 740-750 wide. Sucker ratio 1: 1.25-1.59 (1.49). Testes 2, oval, in tandem. Anterior testis at 800 (10.2\% of BL) to posterior margin of ventral sucker, $640-$ 730 long, 450-570 wide; posterior testis 710-750 long, 410500 wide. Seminal vesicle bipartite, anterior to acetabulum; proximal portion 130-250 long, 150-160 wide, distal portion 170 long, 190 wide. Genital pore at 890 (11.32\% of BL) from anterior end of body. Ovary pretesticular, sinistral, at 450 (5.72\% of BL) to posterior margin of ventral sucker, $450-520$ (470) long, 300-390 (350) wide. Vitellaria 2 clusters of preovarian follicles, at $100-370(1.3-4.7 \%$ of BL) to posterior margin of ventral sucker, right vitellarium with 12 follicles, left vitellarium with $7-8$ follicles (Fig. 5B). Mehlis' gland dorsal at junction of vitelline duct. Laurer's canal opening dorsally between vitellarium, ovary, and anterior testis (Fig. 5C). Uterine loops filling postacetabular region. Eggs 27-32 (29) long, 17 wide. Excretory vesicle Y-shaped, bifurcation at level of vitellaria. Excretory pore terminal. 
TABLE I. Species of Gorgoderina Looss, 1902. BL = body length $(\mathrm{mm}) ;$ OS $=$ oral sucker; Ac $=$ acetabulum.

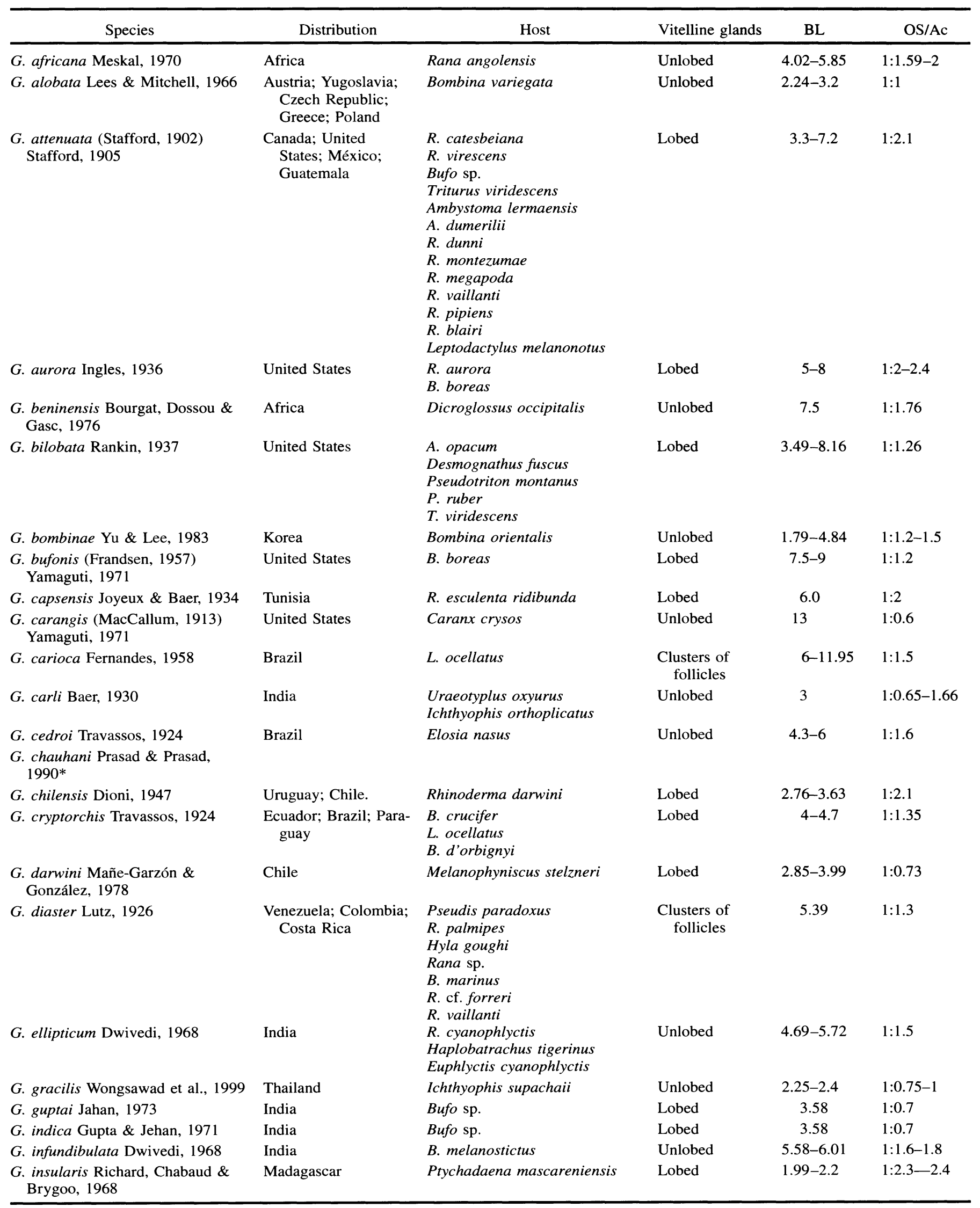


Table I. Continued.

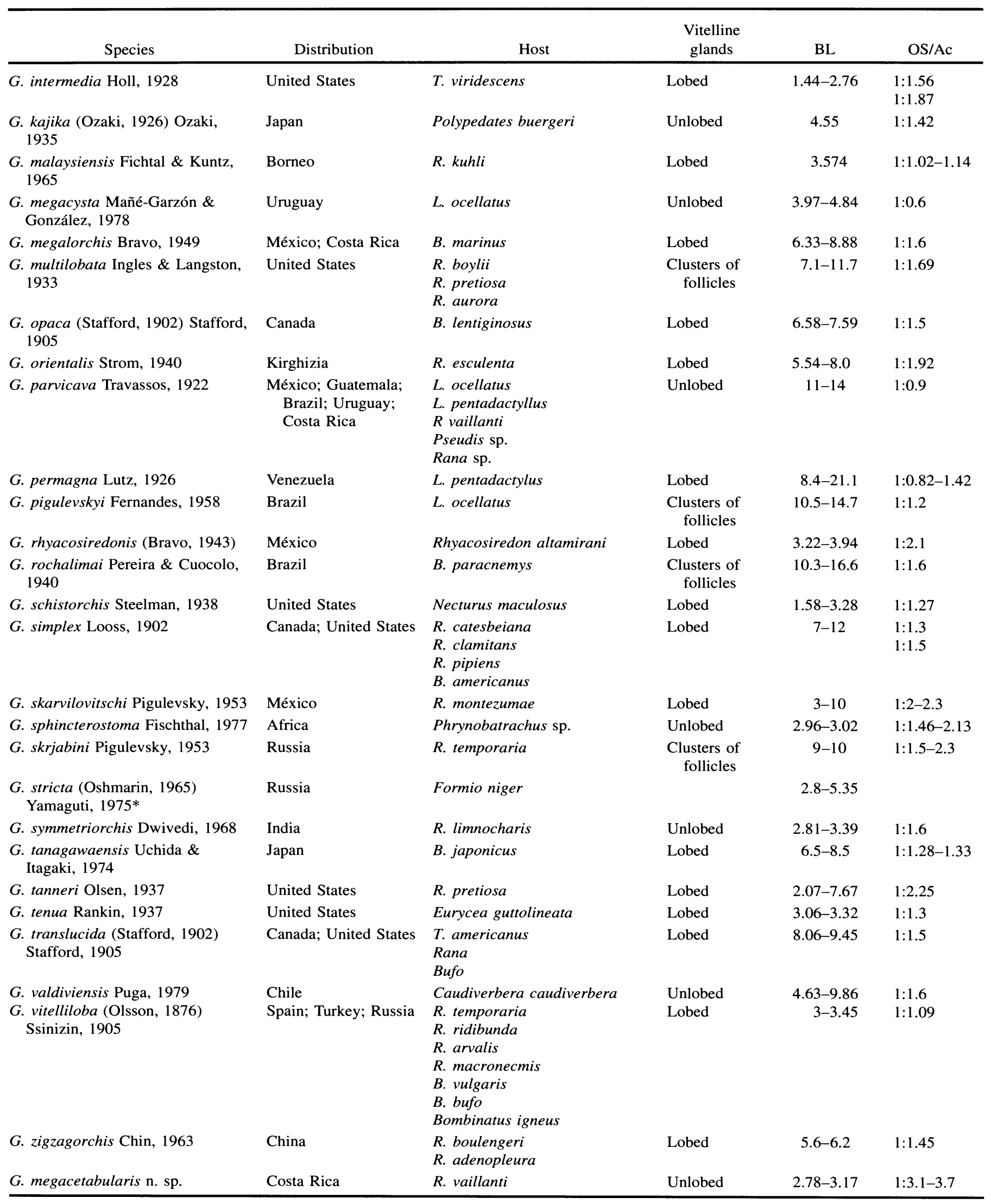

* Cited in reviewed literature; original descriptions were unavailable. 

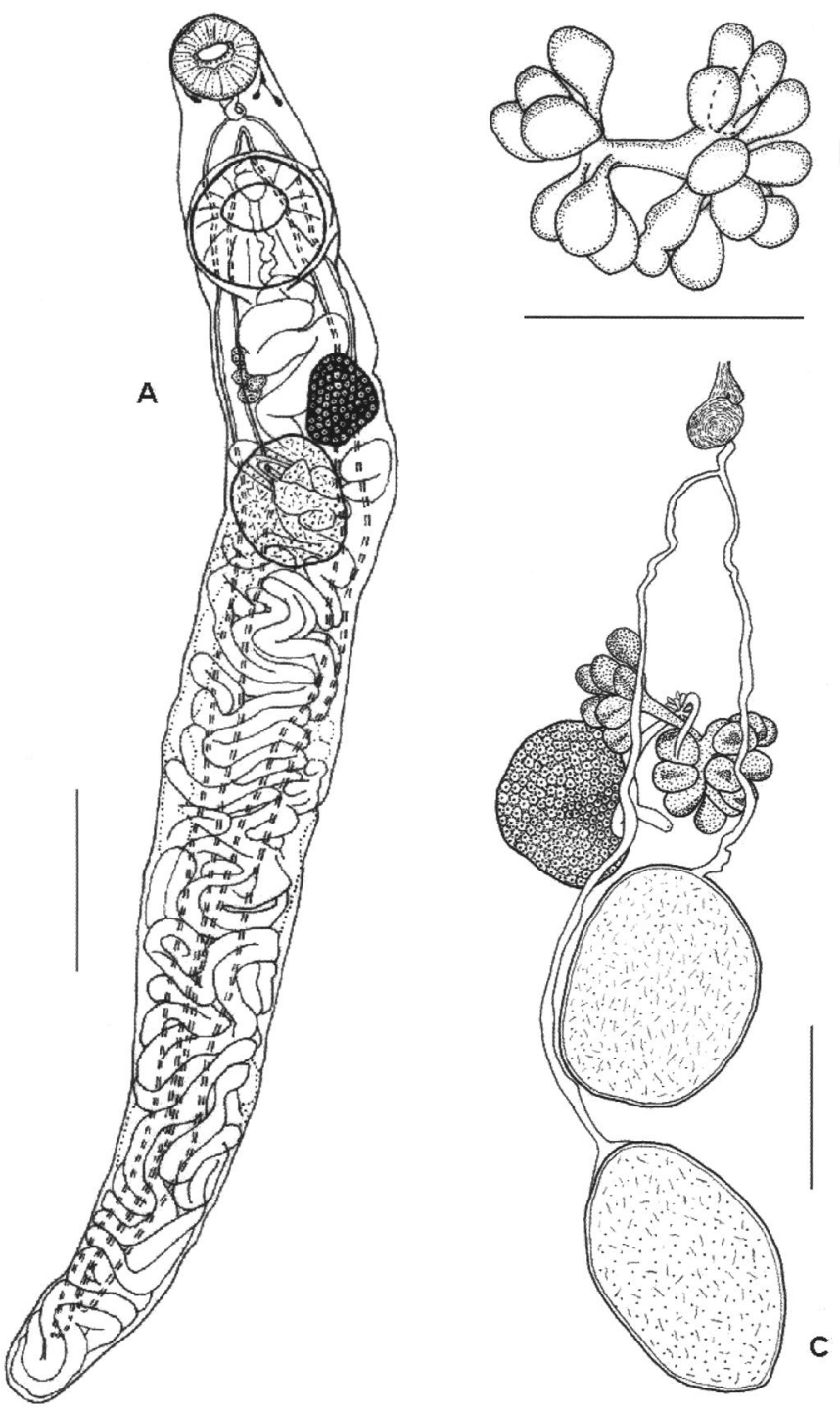

FIGURE 5. Gorgoderina diaster. A. Ventral view. Bar $=1,000 \mu \mathrm{m}$. B. Vitelline glands. Bar $=300 \mu \mathrm{m}$. C. Mehlis' gland, Laurer's canal, ovary, and testes. Bar $=500 \mu \mathrm{m}$.

\section{Taxonomic summary}

Host: Rana vaillanti Brocchi, 1877; R. cf. forreri Boulenger, 1883 (Anura: Ranidae), new host, new record.

Site of infection: Urinary bladder.

Prevalence, intensity: See Table II.

Co-occurrence: With G. megacetabularis n. sp. in 2 specimens of $R$. vaillanti.

Locality: Río Pizote between Brasilia and Dos Ríos, sector San Gerardo, ACG, Costa Rica (R. vaillanti).

Other localities: Laguna Los Jicaros, sector Santa Elena; Camino a Playa Naranjo, sector Santa Rosa, ACG, Costa Rica (R. cf. forreri).

Vouchers: CNHE 4984

Previous records: Rana palmipes and Pseudis paradoxa from Maracay, Venezuela (Lutz, 1928; Fernandes, 1958); Bufo marinus from $15 \mathrm{~km}$ west of Neiva, Huila, Colombia (Brooks, 1976), and from King Rhom, Jamaica (voucher NHM1980.11.12.7-8); new record.

\section{Remarks}

The original description of $G$. diaster (Lutz, 1926) is inadequate. Fernandes (1958) redescribed this species adding some morphometric information, but he based his observations on 1 single specimen. In this study, previously undescribed details about the male and female reproductive apparatus, penetration glands, and additional morphometric data are provided, based on the study of the material collected by Lutz-CHIOC17426, 25255, 25256-and on the material collected in Guanacaste.

\section{ADDITIONAL OBSERVATIONS}

\section{Gorgoderina parvicava Travassos, 1922}

\section{Taxonomic summary}

Host: Rana vaillanti Brocchi, 1877 (Anura: Ranidae).

Site of infection: Urinary bladder.

Prevalence, intensity: See Table II.

Co-occurrence: With G. megacetabularis n. sp. in 2 specimens of $R$. vaillanti.

Locality: Río Pizote between Dos Ríos and Brasilia, sector San Cristobal, ACG, Costa Rica, new locality.

Vouchers: CNHE 4985, 4986.

Previous records: Leptodactyllus ocellatus from Provincia do Manguinhos, Angra dos Reis, São Paulo, Brazil (Travassos, 1922), Recife (Chacon, Cordeiro, Engenho do Meio, Tejipió,

TABLE II. Prevalence (P) and intensity (I) of Gorgoderina diaster, G. parvicava, and G. megacetabularis n. sp. in Rana vaillanti (Rv) and R. cf. forreri (Rf) of Guanacaste, Costa Rica.

\begin{tabular}{|c|c|c|c|c|c|}
\hline & & \multicolumn{2}{|c|}{1998} & \multicolumn{2}{|c|}{1999} \\
\hline Number of Examined specimens & & 44 & 26 & 13 & 13 \\
\hline Gorgoderina diaster & I & $2 / 1$ & 0 & 0 & $4 / 1$ \\
\hline \multirow[t]{2}{*}{ Gorgoderina parvicava } & $\mathrm{P}$ & 0 & 0 & $3 / 13(23.1 \%)$ & 0 \\
\hline & I & 0 & 0 & $16 / 3$ & 0 \\
\hline
\end{tabular}


Tórre) and Cavaleiro (Municipio de Jaboatão), Estado de Pernambuco, Brazil (Dobbin, 1957); Volta Redonda, Río de Janeiro, Brazil (Vicente and dos Santos, 1976; Faria, 1978) and Lake Diario, Maldonado, Uruguay (Mañe-Garzón and González, 1978); L. pentadactyllus labyrinthicus from Recife (Chacon, Cordeiro, Engenho do Meio, Tejipió, Tórre) and Cavaleiro (Municipio de Jaboatão), Estado de Pernambuco, Brazil (Dobbin, 1957), Belo Horizonte, and Minas Gerais, Brazil (Fernandes, 1958); Rana sp. from La Guardianía de Macá, Municipio de Santa Bárbara, Suchitepéquez, Guatemala (Caballero, 1946); R. vaillanti from Los Tuxtlas, Veracruz, México (Guillén-Hernández et al., 2000; Paredes-Calderón et al., 2004).

\section{DISCUSSION}

Pereira and Cuocolo (1940), Pigulevsky (1953), and Fernandes (1958) separately proposed subgeneric divisions within Gorgoderina, mainly based on the structure and position of vitelline glands. However, the characters they used are variable among the genera in the Gorgoderidae. Therefore, we do not consider any subgeneric divisions in this study.

This is the second report of Gorgoderina in Costa Rica. Caballero et al. (1957) reported $G$. megalorchis Bravo-Hollis, 1948 in Rana sp. from Piedades de Santa Ana, Provincia de San José (Rodríguez-Ortíz et al., 2003). This study expands our knowledge of the distribution of some trematodes of Rana hosts through new parts of its range. These new records of Gorgoderina spp. in Costa Rica suggest historical affinities with the host groups.

Gorgoderina diaster has been reported previously in Venezuela in R. palmipes, Pseudis paradoxus, and Hyla goughi and in Colombia in $B$. marinus. In a phylogenetic study of the $R$. palmipes complex based on morphological and molecular characters, Hillis and de Sá (1988) suggest that $R$. vaillanti and $R$. palmipes are sister species. According to their proposal, the Andes of South America are the primary geographical barrier between these 2 species. Rana vaillanti is distributed in the lowland tropical forests west of the Andes and north into Central America, whereas $R$. palmipes is restricted to the lowland tropical forests east of the Andes. The presence of this digenean species in both host species may suggest an ancestral association between the parasite and the ancestor of $R$. vaillanti and $R$. palmipes. It also suggests that both host species share similar environmental conditions and feeding habits.

Gorgoderina parvicava occurs in México in $R$. vaillanti, in Guatemala in Rana sp., and in Brazil in Leptodactylus spp. and Bufo spp. These records indicate an extensive neotropical distribution, probably reflecting the distribution of their preferred hosts.

Whether G. megacetabularis n. sp. originated with the speciation of $R$. vaillanti or as a host-switching event from other amphibians in the region can only be tested with a phylogenetic hypothesis for species of Gorgoderina. Rana vaillanti has also been recorded as host of $G$. attenuata and $G$. parvicava in Los Tuxtlas, Veracruz, México, with a total of 4 species of Gorgoderina recorded in this host species. Rana vaillanti has predominantly aquatic habits that favor the completion of the life cycle of Gorgoderina and many other digeneans. This characteristic, together with its wide geographic range probably also favors speciation events by host switching of parasites that typ- ically infect other amphibians. A similar case occurs with $G$. attenuata, known in green frogs $(R$. clamitans), bull frogs $(R$. catesbeiana), and leopard frogs (of wich $R$. forreri is a member) in North America.

\section{ACKNOWLEDGMENTS}

We are grateful to the scientific and technical staff of the ACG for support of this study, in particular: Elda Araya, Roger Blanco, Carolina Cano, Maria Marta Chavarría, Felipe Chavarría, Roberto Espinoza, Dunia Garcia, Guillermo Jiménez, Elba López, Sigifredo Marín, Alejandro Masis, Calixto Moraga, Fredy Quesada, and Petrona Rios. Thanks also to Dan Janzen and Winnie Hallwachs, scientific advisers to the ACG, for their support. We are grateful to Luis García Prieto (CNHE), Dely Noronha de Bragaça and Luis Muñiz (CHIOC), Scott Gardner (HWML), Donald McAlpine (NBM), Eileen Harris (NHM), and Pat Pilitt (USNPC) for the loan of specimens. Special thanks to Berenit Mendoza Garfias for her help in scanning electron microscopy (SEM), and Gerardo Pérez-Ponce de León and Adrián Nieto Montes de Oca for revising a preliminary version of the manuscript. This study was funded by a research grant from the Natural Sciences and Engineering Research Council (NSERC) of Canada to D.R.B.

\section{LITERATURE CITED}

Brooks, D. R. 1976. Five species of platyhelminths from Bufo marinus L. (Anura: Bufonidae) in Colombia with descriptions of Cretotrema lynchi sp. n. (Digenea: Allocreadiidae) and Glypthelmins robustus sp. n. (Digenea: Macroderoididae). Journal of Parasitology 62: $429-433$.

Caballero, C. E. 1946. Estudios helmintológicos de la región Oncocercosa de México y de la República de Guatemala. Trematoda. II. Presencia de Paragonimus en reservorios naturales y descripción de un nuevo género. Anales del Instituto de Biología, Universidad Nacional Autónoma de México 17: 137-165.

- , R. R. BRENES, AND O. JIMÉNEZ-QUIRÓS. 1957. Helmintos de la República de Costa Rica. Algunos tremátodos de animales domésticos y silvestres. Revista de Biología Tropical 5: 135-155.

Cabrera-Guzmán, E., V. León-Règagnon, and L. García-Prieto. 2005. Helminth infracommunities of leopard frog Rana forreri (Amphibia: Ranidae) in Acapulco municipality in Guerrero, Mexico. Comparative Parasitology. [In press.]

DESSER, S. S. 2001. The blood parasites of anurans from Costa Rica with reflections on the taxonomy of their trypanosomes. Journal of Parasitology 87: 152-160.

DobBin, J. E. 1957. Fauna Helmintológica de batráquios de Pernambuco, Brasil. I. Trematoda. Separata dos Anais da Sociedade de Biologia de Pernambuco 15: 29-61.

FARIA, M. J. DE. 1978. Prevaléncia de trematódeos parasites de anfibios anuros, n. estado do Rio de Janeiro. Atas da Sociedade de Biología do Rio de Janeiro 19: 55-57.

FERNANDES, J. C. 1958. Notas sobre algumas espécies do genero Gorgoderina Looss, 1902 (Trematoda: Gorgoderidae). Memorias do Instituto Oswaldo Cruz 56: 1-15.

Flores-Villela, O., F. Mendoza-Quijano, G. P. González, and E. PÉREZ-RAMOS. 1995. Recopilación de claves para la determinación de anfibios y reptiles de México. Publicaciones Especiales del Museo de Zoología de la Facultad de Ciencias, 10. Universidad Nacional Autónoma de México, México City, D.F., México, 285 p.

GoldBERG, S. R., AND C. R. BURSEY. 2002. Helminth parasites of seven anuran species from Northwestern Mexico. Western North American Naturalist 62: 160-169.

G. Salgado-Maldonado, R. Báez, and C. Cañeda. 2002. Helminth parasites of six species of anurans from Los Tuxtlas and Catemaco Lake, Veracruz, México. Southwestern Naturalist 47: 293-299.

Guillén-Hernández, S., G. Salgado-Maldonado, and R. LamotheARGUMEDo. 2000. Digeneans (Platyhelminthes: Trematoda) of seven sympatric species of anurans from Los Tuxtlas, Veracruz, México. Studies of the Neotropical Fauna and Environment 35: 10-13.

HILlIS, D., AND R. DE SÁ. 1988. Phylogeny and taxonomy of the Rana palmipes group (Salientia: Ranidae). Herpetological Monographs 2: 1-26. 
$\rightarrow \longrightarrow$, J. S. Frost, AND D. A. WRIGHT. 1983. Phylogeny and biogeography of the Rana pipiens complex: a biochemical evaluation. Systematic Zoology 32: 132-143.

$\rightarrow$ León-Règagnon, V., D. R. Brooks, ANd D. A. Zelmer. 2001. Morphological and molecular description of Haematoloechus meridionalis n. sp. (Digenea: Plagiorchioidea: Haematoloechidae) from Rana vaillanti Brocchi of Guanacaste, Costa Rica. Journal of Parasitology 87: 1423-1427.

LUTZ, A. 1928. Estudios sobre trematodes observados en Venezuela. In Estudios de zoología y parasitología Venezolanas (1st Ed.), p. 101105.

MAÑE-GaRzón, F., AND L. R. GonZÁLEZ. 1978. Dos especies del genera Gorgoderina (Gorgorimma) de la vejiga turinaria de Leptodactylus ocellatus (L.) del Uruguay. Revista de Biologa del Uruguay 6: 4550.

$\rightarrow$ Margolis, L., G. W. Esch, J. C. Holmes, A. M. Kuris, And G. A SCHAD. 1982. The use of ecological terms in parasitology (Report of an ad hoc committee of the American Society of Parasitologists). Journal of Parasitology 68: 131-133.

MEYeR, J. R., AND L. D. WILSON. 1971. A distributional checklist of the amphibians of Honduras. Contributions in Science of the Natural History Museum of Los Angeles County 218: 1-47.

$\rightarrow$ Paredes-Calderón, C. E. L., V. León-RĖgagnon, and L. García-PrieTO. 2004. Helminth infracommunities of Rana vaillanti Brocchi (Anura: Ranidae) in Los Tuxtlas, Veracruz, México. Journal of Parasitology. 90: 692-696.

Pereira, C., AND R. Cuocolo. 1940. Trematoides vesicais de anfibio do nordeste brasileiro. Arquivos do Instituto de Biología 11: 413420 .
Pérez-Ponce de León, G., V. León-Règagnon, L. García-Prieto, U. RAZO-MENDIVIL, AND A. SÁNCHEZ-Álvarez. 2000. Digenean fauna of amphibians from Central México: nearctic and neotropical influences. Comparative Parasitology 67: 92-106.

Pigulevsky, S. W. 1953. Family Gorgoderidae Looss, 1901. In Trematodes of animals and man; vol. VIII, K. I. Skrjabin (ed.). Akademya Nauk, Moscow, Russia, p. 251-618.

Razo-Mendivil, U., J. P. Laclette, and G. Pérez-Ponce de León. 1999. New host and locality records of three species of Glypthelmins (Digenea: Macrideroididae) in anurans of México. Journal of the Helminthological Society of Washington 66: 197-201.

Rodríguez-Ortíz, B., L García-Prieto, and G. Pérez-Ponce de León. 2003. Checklist of the helminth parasites of vertebrates in Costa Rica. Revista de Biología Tropical 51: 1-41.

TRAvassos, L. 1922. Contribuçoes para o conhecimento da fauna helmintologica brasileira. Especies brazileiras da Familia Gorgoderidae Looss, 1901. Brazil Médico 1: 17-20.

Vicente, J. J., and E. Dos Santos. 1976. Fauna Helmintológica de Leptodactylus ocellatus (L., 1758) de Volta Redonda, Estado do Rio de Janeiro. Atas da Sociedade de Biologia de Rio de Janeiro 18: $27-42$.

Zaldivar-Riverón, A., V. León-Règagnon, And A. Nieto-Montes de OCA. 2004. Phylogeny of the Mexican coastal leopard frogs of the Rana berlandieri group based on mitDNA sequences. Molecular Phylogenetics and Evolution 30: 38-49.

Zelmer, D. A., AND D. R. BRooKs. 2000. Halipegus eschi n. sp. (Digenea: Hemiuridae) in Rana vaillanti fron Guanacaste, Costa Rica. Journal of Parasitology 86: 1114-1117. 